\title{
IMPACT OF CHANGES IN A PROJECT TEAM STRUCTURE ON THE TEAM PERFORMANCE
}

\author{
Ivana Šandrk Nukić \\ Josip Juraj Strossmayer University of Osijek, Faculty of Civil Engineering Osijek, Ph.D. \\ Corresponding author: isandrknukic@gfos.hr \\ Mario Galić \\ Josip Juraj Strossmayer University of Osijek, Faculty of Civil Engineering Osijek, mag.ing.aedif. \\ Zlata Dolaček-Alduk \\ Josip Juraj Strossmayer University of Osijek, Faculty of Civil Engineering Osijek, Assistant Professor
}

\begin{abstract}
Structuring a project team is highly sensitive task, so numerous methods which address the problem have emerged. One of the most effective methods is structuring teams by the team members' affinities and talents presented as team roles. In this paper, we applied Belbin's Self-Perception Inventory in order to investigate the following questions: Which are the most engaged team roles? How does the absence of the most engaged team members affect the team's efficiency? How does this change of the team environment affect the member? Our results show that, even in small project teams, changes in team structure will surely have a negative effect on the team's organizational culture in a short run, and even more importantly they decrease the team's overall productivity. Also, the changes had a negative effect at the individual level; teams had trouble integrating new members, and individuals had trouble integrating themselves in new teams.
\end{abstract}

Keywords: team role, team structure, team management, project team, performance

\section{UTJECAJ PROMJENA U STRUKTURI PROJEKTNIH TIMOVA NA TIMSKU USPJEŠNOST}

Sažetak: Važnost strukturiranja projektnih timova u građevinarstvu danas se često zanemaruje zbog razvoja i afirmacije novih koncepata i metoda informatičke tehnologije koji se primjenjuju u projektnom menadžmentu. Strukturiranje projektnog tima izuzetno je zahtjevan zadatak i kao takav treba precizan i dobro organiziran sustav i upravljanje. Postoji nekoliko metoda koje se bave tim problemom. Strukturiranje tima prema afinitetima i talentima njegovih članova, koje se naziva timskim ulogama, dobro je poznata i provjereno učinkovita metoda. Autori su u istraživanju predstavljenom ovim radom primijenili Belbin metodu timskih uloga kako bi istražili koje su najangažiranije timske uloge, kako izostanak najangažiranijih članova utječe na učinkovitost tima te kako ta promjena timske okoline utječe na članove. Rezultati su pokazali da, čak i u malim timovima, promjene timske strukture sigurno imaju negativan utjecaj na organizacijsku kulturu tima već u kratkom roku, ali što je još važnije, dugoročno smanjuju cjelokupnu učinkovitost tima. Promjene su imale negativan učinak i na nivou pojedinca, reflektirajući se u činjenici da su se novi članovi teško integrirali u svoje nove timove, odnosno drugi članovi su teško prihvaćali novog.

Ključne riječi: timska uloga, timska struktura, upravljanje timom, projektni tim, učinkovitost 


\section{INTRODUCTION}

Skills are usually being differentiated as basic, generic, and specific skills [1]. Basic skills include literacy and numeracy, while generic skills include teamwork and communication. Although each sector has different needs, they all require development of both basic and generic skills to varying degrees; only specific skills are less transferable between occupations. Furthermore, generic skills (i.e., social skills) have been shown to contribute improve performance [2], making them relevant to future employability.

Ehiyazaryan and Barraclough [3] found a connection between employer engagement, group work in highereducation institutions, and successful development of employability (social, generic) skills. However, this connection has not been sufficiently studied in the context of higher-education institutions in civil engineering and construction fields. Because of this gap, we studied one of these social skills in the context of civil engineering: teamwork.

In this article, we present a study on team management and team roles conducted among civil engineering students. We aimed to find whether knowledge of team role theory could be used to support engineering students in academic teamwork. Our secondary research goal was to study how team roles affected team performance in educational tasks given to students, and how teams and team members react to changes in organizational structure. The research was conducted by using Belbin's Team Role Self-Perception Inventory1.

These research goals match those of a previous study that used the same method [4], which strongly recommended that engineering curricula should incorporate activities that foster creativity among engineers, motivating their collaboration in a problem-solving and project-based environment.

\section{THEORETICAL BACKGROUND}

Companies have always used teamwork in order to improve overall performance. Research shows that teams are more successful than individuals when tasks ask for varying skills, judgment, and knowledge $[5,6]$. To improve performance and competitiveness, companies are being restructured in ways that use the various talents of their employees more effectively. Managers have realized that teams are more flexible, more motivating, and more successful than traditional departments.

Recent research has shown that for construction projects it is crucial to have clear and realistic goals and plans, as well as knowledge of the team members' competences [7]. This importance of teamwork factors motivates us to study the development of teamwork skills among engineering students. To begin, we will discuss the background of team management and team composition theory.

\subsection{Team management}

To do their best work consistently, teams must be carefully formed and managed. Various researchers have studied the factors that affect team efficiency². Those factors can be organized in four categories, as shown in Table 1. Team management must consider all these factors, so we briefly consider them here. However, in forming the necessary theoretical framework for the empirical part of our work, we focus only on the factors of team composition, especially team roles.

Table 1 Factors influencing team effectiveness [6]

\begin{tabular}{l|l|l|l}
\hline \multicolumn{1}{c|}{ Context } & \multicolumn{1}{|c|}{ Work design } & \multicolumn{1}{c}{ Process } & \multicolumn{1}{c}{ Team composition } \\
\hline Sufficient resources & Autonomy & Social loafing & Size \\
Leadership and structure & Variety of skills & Mutual purpose & Diversity \\
Existence of trust & Task identity & Specific goals & Personality \\
System for performance & Task importance & Team self-efficiency & Flexibility of team members \\
evaluation and remuneration & & Conflict & Team members' ability \\
& & & Preferences of team members \\
& & & Assigning roles \\
\hline
\end{tabular}

${ }^{1}$ Belbin's Team Role Self-Perception Inventory is a questionnaire on how an individual sees their behavior within the workplace. It is important because the characteristics identified may not be the behaviors that others pinpoint or value. As such, the questionnaire results help managers structure efficient teams and help team members build successful working relationships with their colleagues and managers.

2 Gladstein, D. L.1984: Groups in context: a model of task group effectiveness. Administrative Science Quarterly, December, 499-517. Campion, M. A., Medsker, G. J., Higgs, C. A. 1993: Relations between Work Group Characteristics and effectiveness: implications for designing effective work groups. Personnel Psychology, winter, 823-850. Guzzo, R. A., Dickson, M. W. 1996: Teams in organizations: recent research on performance and effectiveness in Spence, J. T., Darley, J. M., Foss, D. J. (Eds.) Annual Review of Psyschology, Vol. 47, 307-338 


\subsubsection{Context}

The contextual factors that appear to be most significantly associated with team performance are sufficient resources, leadership and structure, trust, and a system for performance evaluation and remuneration.

Teams are part of a larger organizational system, so they naturally rely on outside resources, and a lack of those resources hinders the team [8]. Based on the team leadership and structure, a work schedule should be determined, required skills identified, and the ways of making decisions and resolving conflicts defined [9]. Members of successful teams believe in each other and in their leaders, so they come to cooperate more naturally and find no need for constant control. In an atmosphere of trust, team members are even willing to reveal their weaknesses and entrust part of the mutual work to a colleague [10].

Teams are considered dynamic social networks in which team members are nodes and members' awareness of other members during ongoing performance are relations. One team member in each team often heeds or is heeded by his teammates, indicating the member's leadership role. Changes in such a network affect the team's performance [11].

Finally, a team's performance is more than just a sum of the individual contributions of the team members [6], so the motivation and remuneration system must consider both the team and individual levels.

\subsubsection{Work design}

Work design includes variables such as freedom and autonomy, opportunities to use different skills and talents, the possibility of completing whole and identifiable tasks or products, and the possibility of working on tasks or projects that significantly impact others [6]. These variables are motivating because they enhance the team members' sense of responsibility and make the work more interesting, improving the team's performance.

\subsubsection{Process}

The process variables influencing a team's performance are the team members' devotion to the mutual purpose, the definition of specific team goals, the team's effectiveness, a specific degree of conflicts, and minimized social loafing. Most of these variables are straightforward, but what is social loafing? It could be described as entropy: it is human nature that, in teamwork when the contribution of each member is not clear, individual members reduce their effort [12]. To diminish this tendency, team members must be constantly asked to take both individual and group responsibility for the purpose, goals, and approach to the work [13].

In this paper, we focus on team roles and their correlation with team performance. Team composition as a factor influencing team effectiveness shall be studied separately.

\subsection{Team composition}

When considering team composition, the first aspect to be discussed is usually its size. Many studies ${ }^{3}$ have aimed to define the best team size, and the general consensus is that the most efficient teams have no more than ten members [6]. If more members are needed, sub-groups should be considered [14].

Furthermore, variety in team members is indispensable for the team to be efficient and successful, not only in professional specialties and experience, but also in gender, age, education, and personality $[15,16]$. Personality is usually connected to individual achievement, but it also strongly influences performance on the team level.

In some cases, flexibility might be a significant advantage because it improves the team's adaptability and makes it less dependent on any individual member [17]. Of course, a team's performance depends on the knowhow and skills of its members. It is generally accepted that an efficient team requires three types of abilities: technical abilities, problem-solving and decision-making abilities, and interpersonal abilities [6].

\footnotetext{
${ }^{3}$ Curral, L. A., Forester, R. H., Dawson, J. F., West, M. A. 2001: It's what you do and the way that you do it: team task, team size and Innovation-related group processes. European Journal of Work \& Organizational Psychology Vol. 10, No. 2, 187-204. Liden, R. C., Wayne, S. J., Jaworski, R. A. 2004: Social loafing: a field investigation. Journal of Management Vol. 30, No. 2, 285-304. Wagner, J. A. 1995: Studies of individualism-Collectivism: Effects on Cooperation in Groups. Academy of Management Journal Vol. 38, No. 1152-172
} 
A team cannot be efficient without all three types; only their structure depends on the nature of the team's task. When forming a team, it is extremely important to determine whether an employee prefers collaborative work or individual work. Some people might have the needed skills and abilities but enjoy individual work more than collaborative work, and including such employees in a team can jeopardize the team's motivation and the satisfaction of its other members [17].

Appreciating all of the above stated, it is evident that teams are complex entities and should be composed of members who can practice different team roles. The team role can be defined as the expected behavior related to the position that a group member holds in the team structure [18]. Team role suggest the specific behavior that others expect from a team member and that he expects of himself, considering his status in the social structure. That expected behavior (i.e., the role) depends on the team member's personal characteristics and interests. As such, team roles are the characteristic manner in which team members interact with each other, and those interactions facilitate the progress of the team.

Because teams generally have two basic functions, task accomplishment and fulfillment of the members' social needs, successful teams have two key types of team roles: roles focused on the task and roles focused on social relations [18]. The team members in roles focused on the task invest their time and energy in achieving business objectives, and their behaviors include encouraging ideas and actions, analyzing and evaluating ideas and solutions, searching and gathering necessary information, and organizing activities. On the other hand, team members in socio-emotional roles provide support and ensure the social unity of the team. They support other members, reduce tensions and ensure harmony, and encourage compromises and subjugation of personal opinions and goals to the welfare of the team.

Different roles are performed by different team members. Long-term research on roles in successful teams point to a number of different necessary roles, and it emphasizes that roles must be balanced and must complement the characteristics of the members who fill them [19]. Diversity and complementarity of roles is crucial for team performance, which places great responsibility on managers structuring the team. By using questionnaires and personal experience, managers should select team members based on their personal qualities and interests, then assign tasks accordingly. When a manager aligns a member's preferences with the requirements of their team role, the team's members will be more likely to work well together. In the empirical part of our study, we use Belbin's team role approach, which we describe in more detail later.

\section{RESEARCH METHODOLOGY}

The main motivations of this research were to investigate whether knowledge of team role theory could be used to support teamwork, to detect how team roles affect team performance, to study how changing the team member filling a team role affects the team's productivity, and to assess specific aspects of the organizational culture (e.g., form of paper, form of team meetings, way of graphical presentation, form of reports, way of communication in team). We were also motivated by previous workshops, after which the students commented on their satisfaction with developing specific engineering skills and methods to deal with the real-life problems, situations, and people that add to the complexity of construction management tasks [20]. However, they also noticed the importance of social skills, stating that they found problems working in teams, unfair allocation of work, unequal engagement with assignments by team members, and the team needing a leader and strict guidance in order to be efficient.

The study presented in this paper was conducted at the Faculty of Civil Engineering Osijek, among Project Management course students in their second semester of graduate study. The survey was conducted during a mandatory term paper and consisted of two similar assignments (number of students $N=19$ ). The students were divided into four groups and distributed based on the results of Belbin's test, which separated participants into primary and secondary team roles. We gave each team a fifteen-minute oral presentation, giving them instructions for their assignments and warning them that adherence to the instructions will be included in the paper's final grade.

The study was conducted in four interconnected phases, as shown in Figure 1. In the first stage, we formed the initial project team for the first assignment. The participants completed a standardized Belbin's test and were asked to appoint a primary and secondary role for themselves and for each colleague.

Our survey participants had some previous experience with their colleagues, which we used in determining team roles. The chosen team roles depended $80 \%$ on the results of Belbin's tests and $20 \%$ on how the respondents described themselves and their colleagues. 


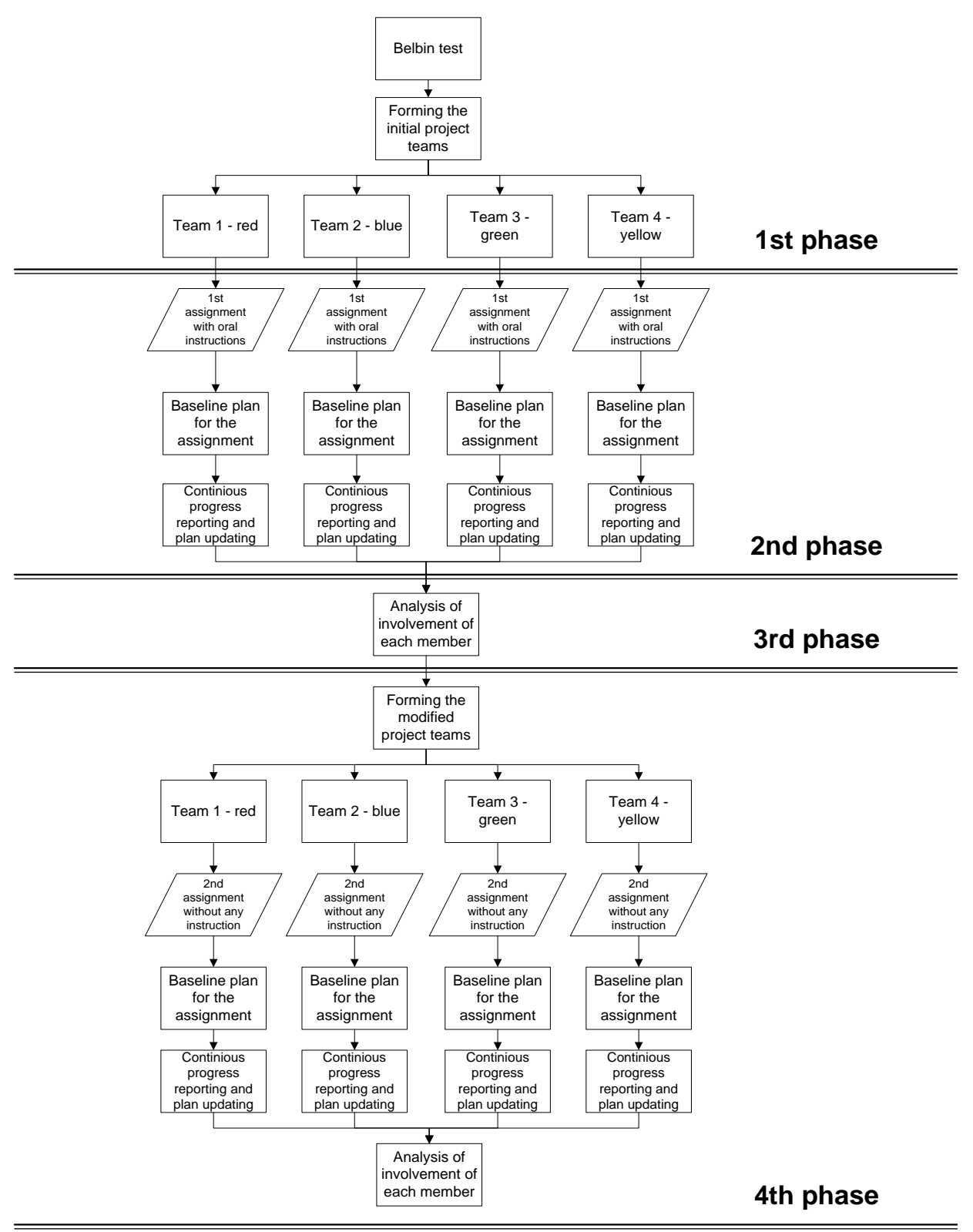

Figure 1 Flowchart of the survey

In the second phase, we monitored the groups' weekly progress reports on the first assignment. In the third stage, we analyzed the involvement of all teams and each team member depending on the member's primary role (PTR) and secondary role (STR) in the team. In the fourth stage, we transferred the most engaged members to the other team and monitored the second assignment.

Most researchers agree that people can engage in infinite types of behavior, even in similar situations and occupations. However, the range of useful behaviors, which effectively contribute to the team's performance, are noted and grouped into related clusters, termed the team roles. Belbin [19] noted that there are eight standard roles and one additional role: plant (PL), resource investigator (RI), co-ordinator (CO), shaper (SH), monitor evaluator $(\mathrm{ME})$, team worker (TW), implementer (IMP), complete finisher (CF), and specialist. Each role can be generally described by a set of characteristics in work situations. Workers are grouped into these roles by completing a test that contains situations with given responses. From these responses, the test identifies the worker as filling either a primary or secondary team role. In the present study, we used a test with only the eight standard roles, not the specialist, which will be added in later research. 
Table 2 Matrix form of the initial project teams

\begin{tabular}{|c|c|c|c|c|c|}
\hline \multicolumn{3}{|l|}{ Team 1} & \multicolumn{3}{|l|}{ Team 2} \\
\hline Team Member code & PTR & STR & Team Member code & PTR & STR \\
\hline TM11 & TW & ME & TM21 & TW & ME \\
\hline TM12 & ME & IMP & TM22 & TW & $\mathrm{SH}$ \\
\hline TM13 & TW & $\mathrm{SH}$ & TM23 & $\mathrm{ME}$ & TW \\
\hline TM14 & IMP & TW & TM24 & $\mathrm{ME}$ & IMP \\
\hline TM15 & IMP & $\mathrm{PL}$ & TM25 & IMP & ME \\
\hline \multicolumn{3}{|l|}{ Team 3} & \multicolumn{3}{|l|}{ Team 4} \\
\hline Team Member code & PTR & STR & Team Member code & PTR & STR \\
\hline TM31 & TW & IMP & TM41 & IMP & ME \\
\hline TM32 & IMP & ME & TM42 & TW & $\mathrm{CO}$ \\
\hline TM33 & TW & $\mathrm{CF}$ & TM43 & TW & IMP \\
\hline TM34 & TW & ME & TM44 & TW & ME \\
\hline TM35 & ME & IMP & & & \\
\hline
\end{tabular}

There is certainly no universal algorithm for structuring a successful team by using only an initial test of any kind. Structuring a team is a process, and as a process it must be planned carefully. It must have a firm baseline plan, for which Belbin's test is an excellent tool. With more workers or participants, it becomes much easier to structure teams because it easier to fill all the team roles. We structured the teams in an attempt to equally distribute the team roles in each team, as shown in Table 2.

\section{RESULTS}

\subsection{Belbin's test}

The results of our Belbin's test highlighted two dominant roles: team worker (TW) and implementer (IMP). This result could be explained by the fact that this survey was conducted among participants with the same level and primary scope of education (organization, technology, and management in construction), but to give a more precise explanation it is necessary to conduct Belbin's test among a larger set of respondents. Furthermore, when a project team is rather small, as in this survey $(N=19)$, it is very hard to structure sub-organizations that have each team role. This result does not fulfill the assumption that Belbin's original management team model requires eight people who each shows a facility for a particular role.

\subsection{First assignment}

When the project teams were structured, each was given similar first assignment and slightly different instructions. For the first task, each team had to make a work baseline plan that specified all the activities needed to complete the assignment, with estimated and actual duration of activities, and the assigned members for each activity. Their work was monitored by the following metrics: elaboration of the baseline plan, weekly reports submitted, ability to follow instructions, elaboration of project, and their final presentation of the first assignment.

Table 3 Team results on the first assignment

\begin{tabular}{|l|c|c|c|c|c|}
\cline { 2 - 6 } \multicolumn{1}{c|}{} & $\begin{array}{l}\text { Elaboration of the } \\
\text { baseline plan }\end{array}$ & $\begin{array}{l}\text { Number of weekly } \\
\text { reports submitted }\end{array}$ & $\begin{array}{l}\text { Ability to follow } \\
\text { given instructions }\end{array}$ & $\begin{array}{l}\text { Project } \\
\text { elaboration }\end{array}$ & $\begin{array}{l}\text { Final presentation } \\
\text { of the assignment }\end{array}$ \\
\hline Team 1 & $70 \%$ & $60 \%$ & $90 \%$ & $80 \%$ & $70 \%$ \\
\hline Team 2 & $75 \%$ & $80 \%$ & $90 \%$ & $90 \%$ & $85 \%$ \\
\hline Team 3 & $85 \%$ & $100 \%$ & $60 \%$ & $95 \%$ & $80 \%$ \\
\hline Team 4 & $75 \%$ & $80 \%$ & $70 \%$ & $95 \%$ & $80 \%$ \\
\hline
\end{tabular}


As shown in Table 3, students had trouble elaborating their work plan. We expected this because they lacked experience on the subject and because they did not appreciate the importance of weekly reports. Project elaboration was the highest-graded metric on the first assignment. Surprisingly, in almost every group the most engaged member was team worker/monitor evaluator, as shown in Table 4, but the other members were almost equally engaged.

Table 4 Distribution of work done by team members on the first assignment

\begin{tabular}{|c|c|c|c|c|c|c|c|}
\hline \multicolumn{9}{|l|}{ Team 1 } & \multicolumn{2}{l|}{ Team 2 } \\
\hline Team Member code & PTR & STR & engagement (\%) & Team Member code & PTR & STR & engagement (\%) \\
\hline TM11 & TW & ME & $28.38 \%$ & TM21 & TW & ME & $16.59 \%$ \\
\hline TM12 & ME & IMP & $16.22 \%$ & TM22 & TW & SH & $20.57 \%$ \\
\hline TM13 & TW & SH & $17.57 \%$ & TM23 & ME & TW & $17.73 \%$ \\
\hline TM14 & IMP & TW & $20.27 \%$ & TM24 & ME & IMP & $23.41 \%$ \\
\hline TM15 & IMP & PL & $17.57 \%$ & TM25 & IMP & ME & $14.32 \%$ \\
\hline \multicolumn{7}{|l|}{ Team 3 3 Team 4 } \\
\hline Team Member code e & PTR & STR & engagement (\%) & Team Member code & PTR & STR & engagement (\%) \\
\hline TM31 & TW & IMP & $10.90 \%$ & TM41 & IMP & ME & $25.07 \%$ \\
\hline TM32 & IMP & ME & $13.83 \%$ & TM42 & TW & CO & $24.51 \%$ \\
\hline TM33 & TW & CF & $18.24 \%$ & TM43 & TW & IMP & $25.07 \%$ \\
\hline TM34 & TW & ME & $21.17 \%$ & TM44 & TW & ME & $25.35 \%$ \\
\hline TM35 & ME & IMP & $35.85 \%$ & \multicolumn{3}{l}{} \\
\hline
\end{tabular}

\subsection{Modified project teams and second assignment}

We structured the modified teams so that individuals with the same mix of primary and secondary roles (IT/ME) were moved to the other team due to the result comparison (TM11 $\rightarrow$ team 4; TM21 $\rightarrow$ team 3; TM34 $\rightarrow$ team 1; TM44 $\rightarrow$ team 2).

After forming the modified teams, all groups were given a second assignment. It was similar to the first one, but without new instructions. It only included a note saying that the team members were to follow the instructions given for the first assignment.

Table 5 Results for the second assignment

\begin{tabular}{|l|c|c|c|c|c|}
\cline { 2 - 5 } \multicolumn{1}{c|}{} & $\begin{array}{l}\text { Elaboration of the } \\
\text { baseline plan }\end{array}$ & $\begin{array}{l}\text { Number of weekly } \\
\text { reports submitted }\end{array}$ & $\begin{array}{l}\text { Ability to follow } \\
\text { given instructions }\end{array}$ & $\begin{array}{l}\text { Project } \\
\text { elaboration }\end{array}$ & $\begin{array}{l}\text { Final presentation } \\
\text { of the assignment }\end{array}$ \\
\hline Team 1 & $80 \%$ & $100 \%$ & $80 \%$ & $80 \%$ & $95 \%$ \\
\hline Team 2 & $90 \%$ & $100 \%$ & $70 \%$ & $95 \%$ & $100 \%$ \\
\hline Team 3 & $75 \%$ & $100 \%$ & $50 \%$ & $80 \%$ & $90 \%$ \\
\hline Team 4 & $90 \%$ & $100 \%$ & $65 \%$ & $80 \%$ & $90 \%$ \\
\hline
\end{tabular}

As shown in Table 5, the modified groups improved their elaboration of work plan and weekly reports, but as expected the new member hindered the ability of the groups to follow instructions.

In the new teams, the transferred members had lower engagement, and they were never the most engaged members of the team. This result might be related to their decrease in following instructions, as shown in Table 6 . 
Table 6 Distribution of work done by each team member on the second assignment

\begin{tabular}{|c|c|c|c|c|c|c|c|}
\hline \multicolumn{7}{|l|}{ Team 1 } & Team 2 \\
\hline TM code & PTR & STR & work done (\%) & TM code & PTR & STR & work done (\%) \\
\hline TM34 & TW & ME & $17.05 \%$ & TM44 & TW & ME & $18.06 \%$ \\
\hline TM12 & ME & IMP & $20.45 \%$ & TM22 & TW & SH & $18.06 \%$ \\
\hline TM13 & TW & SH & $16.67 \%$ & TM23 & ME & TW & $18.06 \%$ \\
\hline TM14 & IMP & TW & $25.38 \%$ & TM24 & ME & IMP & $22.22 \%$ \\
\hline TM15 & IMP & PL & $20.45 \%$ & TM25 & IMP & ME & $23.61 \%$ \\
\hline Team 3 & PTR & STR & work done (\%) & TM code & PTR & STR & work done (\%) \\
\hline TM code & TW & IMP & $11.27 \%$ & TM41 & IMP & ME & $25.28 \%$ \\
\hline TM31 & IMP & ME & $11.27 \%$ & TM42 & TW & CO & $24.43 \%$ \\
\hline TM32 & TW & CF & $16.90 \%$ & TM43 & TW & IMP & $24.92 \%$ \\
\hline TM33 & TW & ME & $12.68 \%$ & TM11 & TW & ME & $25.36 \%$ \\
\hline TM21 & ME & IMP & $47.89 \%$ & & \\
\hline TM35 & IMP &
\end{tabular}

\section{DISCUSSION}

Our results show that, even for a small project team, a change in structure will not only negatively affect the team's organizational culture in the short run, but also decrease the team's productivity, as shown in Table 7.

Table 7 Effect of change in team member on team productivity

\begin{tabular}{|c|c|c|c|c|c|}
\cline { 2 - 6 } \multicolumn{1}{c|}{} & $\begin{array}{c}\text { Elaboration of the } \\
\text { baseline plan }\end{array}$ & $\begin{array}{c}\text { Number of weekly } \\
\text { reports submitted }\end{array}$ & $\begin{array}{c}\text { Ability to follow } \\
\text { given instructions }\end{array}$ & $\begin{array}{c}\text { Project } \\
\text { elaboration }\end{array}$ & $\begin{array}{c}\text { Final presentation } \\
\text { of the assignment }\end{array}$ \\
\hline Team 1 & $\nearrow$ & $\nearrow$ & $\searrow$ & $=$ & $\nearrow$ \\
\hline Team 2 & $\nearrow$ & $\nearrow$ & $\searrow$ & $\nearrow$ & $\nearrow$ \\
\hline Team 3 & $\searrow$ & $\searrow$ & $\searrow$ & $\searrow$ & $\nearrow$ \\
\hline Team 4 & $\nearrow$ & $\nearrow$ & $\searrow$ & $\nearrow$ \\
\hline
\end{tabular}

Participants had trouble integrating the new member into their team. The new member relied on their own previous experience and "way of work," which bothered the other team members and led to the partial exclusion of the new member. As expected, the final presentations of the second assignment improved because of the team's earlier experience. Our results show that Belbin's test can be a useful tool for structuring project teams, even in higher education. This test is especially useful because it helps teachers without experience with particular students form teams. If the teacher lets the students form teams by themselves, they will probably do so based on friendships, which should not be allowed because this method would not be possible in their future professional life.

Such findings agree with a recent study by Senaratne and Gunawardane [21], which confirmed that teams are the primary working unit in the construction industry, meaning the performance of an industry can be improved by improving team performance. They also concluded that team composition is a key factor in team performance; when considering the team composition, it is relevant to assess the different roles which the members play and how they interact with one another.

\section{CONCLUSIONS}

Structuring a team rarely happens by accident. Forming a team must be carefully planned, with special emphasis on selection, training, and rewarding of team members. Belbin's test can help in that process greatly. Team work is essential in terms of developing engineering students. It is important to develop their generic and teamwork skills so they are more employable. In that process, self-assessment questionnaires on learning styles adapted from theories like Belbin's can be used to support individuals during collaborative activities. It is particularly important to consider learning style profiling from Belbin's work on team size and roles. Knowledge of the team role theory promotes self-awareness and the development of social skills, improving effectiveness at group work. 


\section{References}

[1] Sector skills assessment for the construction sector 2009, available at: http://www.agcas.org.uk/assets/download?file=1512\&parent=561; (access date: 08/11/2014).

[2] Smith, G., Yates, P., 2011: Team role theory in higher education. Training Journal, March, pp. 54-57.

[3] Ehiyazaryan, E.,Barraclough, N., 2009: Enhancing employability: integrating real world experience in the curriculum. Education and Training, 51(4), pp. 292-308., http://dx.doi.org/10.1108/00400910910964575

[4] Ibn-E-Hassan, Talib, N. A., Riaz, A., Iqbal, M. J., 2014: Influence of national and engineering culture on team role selection. International Journal of Technology and Design Education, 24(1), pp. 91-105., http://dx.doi.org/10.1007/s10798-013-9242-z

[5] Laughlin, P., Hatch, E., Silver, J., Boh, L., 2006: Groups Perform Better Than the Best Individuals on Lettersto-Numbers Problems: Effects of Group Size. Journal of Personality and Social Psychology, 90(4), pp. 644651., http://dx.doi.org/10.1037/0022-3514.90.4.644

[6] Robbins, S. P., Judge, T. A., 2009: Organizacijsko ponašanje, 12th edition, Mate, Zagreb.

[7] Gudienè, A., Banaitis, V., Podvezko, N., Banaitienè N., 2014: Identification and evaluation of the critical success factors for construction projects in Lithuania: AHP approach. Journal of Civil Engineering and Management, 20(3), pp. 350-359., http://dx.doi.org/10.3846/13923730.2014.914082

[8] Bishop, J. W., Scott, K. D., Burroughs, S. M., 2000: Support, Commitment and Employee Outcomes in a Team Environment. Journal of Management, 26(6), pp. 1113-1132., http://dx.doi.org/10.1177/014920630002600603

[9] Maginn, M., 2004: Team work - 24 lessons for working together successfully, The McGraw-Hill Professional Education Series, Inc.

[10] Williams, M., 2001: In whom we trust: group membership as an affective context for trust development. Academy of management review, 26(3), pp. 377-396., http://dx.doi.org/10.5465/AMR.2001.4845794

[11] Bourbousson, J., R'Kiouak, M., Eccles, D. W., 2015: The dynamics of team coordination: social network analysis as a window to shared awareness. European Journal of Work and Organizational Psychology, 24(1), pp. 1-19., http://dx.doi.org/10.1080/1359432X.2014.1001977

[12] Liden, R. C., Wayne, S. J., Jaworski, R. A., Bennett, N., 2004: Social loafing: A Field Investigation. Journal of Management, 30(2), pp. 285-304., http://dx.doi.org/10.1016/i.jm.2003.02.002

[13] Katzenbach, J.R., Smith, D. K., 2003: The wisdom of teams: creating the high-performance organization, Harper Collins Business Essentials, NY.

[14] Curral, L. A., Forrester, R. H., Dawson, J. F., West, M. A., 2001: It's what you do and the way that you do it: team task, team size and innovation-related group processes. European Journal of Work \& Organizational Psychology, 10 (2), pp. 187-204., http://dx.doi.org/10.1080/13594320143000627

[15] Jackson, S. E., Joshi, A., Erhardt, N. L., 2003: Recent research on team and organizational diversity: SWOT analysis and implications. Journal of Management, 29(6), pp. 801-830., http://dx.doi.org/10.1016/S01492063 03_00080-1

[16] Van Knippenberg, D., De Dreu, C. K. W., Homan, A. C., 2004: Work Group diversity and group performance: an integrative model and research agenda. Journal of Applied Psychology, 89 (6), pp. 1008-1022., http://dx.doi.org/10.1037/0021-9010.89.6.1008

[17] Sundstrom, E., Meuse, K. P., Futrell, D., 1990: Work teams: applications and effectiveness. American Psychologist, 45(2), pp. 120-133., http://dx.doi.org/10.1037/0003-066X.45.2.120

[18] Bahtijarević-Šiber, F., Sikavica, P., Pološki Vokić, N., 2008: Suvremeni menadžment, Školska knjiga, Zagreb.

[19] Belbin, R. M., 2010: Team Roles at Work, 2nd Edition, Burlington, MA, Butterworth-Heinemann.

[20] Dolacek-Alduk Z., Loncar-Vickovic S., Stober D., 2011: Projektna nastava u obrazovanju građevinskih inženjera, Sveučilište Josipa Jurja Storssmayera u Osijeku, Osijek.

[21] Senaratne, S., Gunawardane, S., 2015: Application of team role theory to construction design teams. Architectural Engineering and Design Management, 11(1), pp. 1-20., http://dx.doi.org/10.1080/17452007.2013.802980 